\title{
LITERACY APPLICATION IN DISCIPLINARY PEDAGOGICAL PRACTICES AT LEGAL ENVIRONMENT
}

\author{
David Alberto Londoño-Vásquez, \& Alvaro Ramírez-Botero \\ School of Social Science, Institución Universitaria de Envigado (Colombia)
}

\begin{abstract}
This oral presentation has been focused on the results of a research on literacy practices in undergraduate law programs at Universidad San Buenaventura (Medellin Campus), a private institution and at Institución Universitaria de Envigado, a public institution, between terms 2017-II and 2018-II, both institutions located in the State of Antioquia (Colombia). For this purpose, a research work was conducted in three phases. During the first phase, the way some theoretical and conceptual perspectives have been employed to talk about comprehension and textual production in the legal environment at higher education institutions in Latin America was reviewed until reaching the term Literacy. The second phase included the development of a field work involving the application of a questionnaire to students attending the legal program from the two schools about three common selected courses. Furthermore, interviews were administered to professors lecturing such courses and the work was executed on a focal group with students who graduated from both schools. During the third phase, the analysis of results was performed based on the initial categories for the analysis: discursive genres, (legal) field, (legal) argumentation, and inter-textuality, as well as some other categories established later, which are deemed as emerging categories: didactics, textual practices, and orality. This allowed concluding that different strategies involving literacy which favor disciplinary learning and the development of professional competences are developed in the professors' pedagogical practices. In most circumstances, however, which is accounted by students, alumni, and professors is employed in a non-intentional manner. As a non-intentional literacy, it is not found at a specific place which allows it to actually operate as a pedagogical mediation intended to favor the teaching-learning processes.
\end{abstract}

Keywords: Law, legal environment, literacy, pedagogical practices, higher education.

\section{Introduction}

The levels of reading and writing in Latin America have been analyzed massively during the last 30 years (Brown, 1999; Carlino, 2005; Parodi, 2008; Zavala, 2009; Londoño, 2015; Navarro et al., 2016). This interest has been consolidated thanks to the relationship between comprehension and textual production in different educational cycles. Such is the case that a relevant number of research works has been focused on understanding the way students entering the University read and write (Carlino, 2005), on describing the relationship between learning and the levels of reading comprehension (Rosenshine, 2005), on explaining the influence of writing processes on learning (Londoño \& Ramírez, 2017), and on revealing the social and political roles of reading and writing for the construction of more critical, autonomous, and democratic citizens (Giroux \& McLaren, 2018), among others..

Recently, however, the research interest has been focused on the analysis of the way reading and writing are frequently being employed at the pedagogical practices of university educational programs (Skerrett \& Bomer, 2011), understanding their role as a pedagogical mediation which is intended to have access to the information from reflection (Alexander, 2017), analysis (Roberge, Losey \& Wald, 2015), and discursive argumentation (Özdem, Cakiroglu, \& Ertepinar, 2017). Having said that, it seems that such comprehension and textual production practices do not always accompany the educational process in a positive manner, either due to the didactic elements present or due to the lack of concepts of students who have recently been involved in these fields of knowledge.

Therefore, some research works have been intended to describe whether the levels of reading and writing developed during the educational process do correspond to the ones required by the employment (Parodi, 2008) and professional (López, 2002) contexts. In other words, if pedagogical practices based on comprehension and textual production are not functional in some cases for the academic educational 
process but they comply with the educational role of the professional persons and allow them to perform in an appropriate manner.

For the abovementioned, literacy (Cassany, 2005) emerges as a theoretical and methodological option suitable for analyzing comprehension and textual production with respect to specific contexts, understanding the text as a social, cultural, and disciplinary construction.

For this reason, the research entitled Literacy in the Legal Environment: Literacy Practices at the Law Schools of Universidad de San Buenaventura and Institución Universitaria de Envigado, executed thanks to a specific agreement between both institutions from academic term 2017-II to academic term 2018-II, was conducted with the purpose of describing literacy practices at both schools as a way of addressing the characteristics practices show around the literacy employed in the field of Law at the institutions named above. Finally, we acknowledge Milton Castellanos and Kennier Garay, professors at University of San Buenaventura (Medellin), who participated in this research.

\section{Design}

This was a qualitative (Patton, 1990) and applied (Bonilla y Rodríguez, 1997) research. This implies that individuals interact with other members within their social context in order to share the knowledge they have about themselves and their reality (Heigham \& Croker, 2009). Based on such definition, this research should be seen as a qualitative work since it is intended to describe the literacy practices at the Law Schools from two universities. Besides, the research is focused on the intervention within a specific context instead of on the development of theories; this being said, the research, in general, "comprises all fields associated to the environment of social technologies which are intended to produce induced or planned changes with the purpose of resolving problems or operating on any aspect of reality" (Ander-Egg, 2003, pp. 41-42). Thus, understanding literacy practices in the field of Law allows the construction of proposals to improve such practices and strengthen the levels of literacy of students and future professionals.

\section{Objective}

The objective of this research was to describe the literacy practices at the Law School of Universidad de San Buenaventura (Medellin Campus) and Institución Universitaria de Envigado. For this purpose, conceptions about literacy assumed by professors and students from both schools were established. Likewise, an inquiry was conducted about those pedagogical practices directly or indirectly associated to elements inherent to literacy. Finally, in conjunction with the participants, potential literacy practices which take place for the daily performance of legal professionals were also identified.

\section{Methods}

The comprehensive hermeneutics was the methodological perspective assumed for this research (Patton, 1990). Therefore, characterization of literacy practices in the field of Law was based on three key concepts: experience, expression, and comprehension. Research was developed in three phases:

\subsection{Phase 1}

This phase included the construction of the state of the art; central categories of research and its basis were defined. To this effect, the documentary revision technique was employed. A selection of articles published between 2007 and 2018 was made on Latin American journals indexed on Latindex. Articles should address the reading and writing processes in the legal environment in both professionals and students. 9 articles were found during the search and they were analyzed by using a constructed rubric. Such rubric allowed identifying and classifying the bibliographic, bibliometric, and discursive information of analyzed texts.

\subsection{Phase 2}

The field work was developed during this phase. The field work consisted of the approach to students, professors, and alumni from the legal schools of the universities named above. The purpose was to collect their opinions, positions, and ideas. They were asked about their experiences and literacy and argumentation practices in education in the legal field and the importance of reading and writing practices in the legal teaching processes and in the professional performance within this discipline. 3 common courses were selected: History of Political Ideas (first academic term), General Procedural Theory (fourth academic term), and Conflict Solution Methods (seventh academic term). A group of alumni from the two schools were further selected for forming a focal group. 
Techniques and instruments employed were as follows: questionnaire (Ander-Egg, 2003) applied to 110 students attending the selected courses (74 students from Institución Universitaria de Envigado and 36 students from Universidad de San Buenaventura). The interviews were administered to 6 professors lecturing such courses. The semi-structured interview guide was employed as the instrument (Bonilla y Rodríguez, 1998). The focal group technique was used with alumni (Vaughn, Schumm \& Sinagub, 1996). The instrument for the entire group was a guide of questions. The inclusion criteria to participate in the focal group were the following: exceeding two years as alumni; having been involved in litigation processes; or having developed functions as a professional in the legal field; not having been a professor; and having given his/her acceptance to participate in the group. The focal group consisted of 4 alumni from the schools.

\subsection{Phase 3}

This phase included the development of the information analysis. The analysis was based on the information collected with the instruments. The data from the questionnaire administered to 110 students was used to perform a statistical analysis, as follows: for the data reduction process, a multivariate factorial analysis was conducted through the Principal Component Analysis method. This analysis included the Kaiser-Meyer-Olkin (KMO) sampling adequacy method and then the Varimax Rotation Technique was applied. On the other side, a qualitative analysis of the interviews applied to six professors of the selected courses was conducted. Relevant transcription and systematization were made on an analytical matrix (Londoño, 2015) in such a way that answers of interviewees were associated to the analysis categories pre-established from the documentary revision. Furthermore, the matrix was employed to review prevalence and reiteration, which suggested the emergence of new categories. The information collected with the focal group was also transcribed. Relevant analysis required a matrix which related the answers to analysis categories employed during the interviews with professors.

\section{Discussion}

Initially, it was possible to establish that the number of research works on literacy in the legal environment was incipent. This is due to the fact that research works have been mainly focused on the inquiry about aspects of form; this corresponds to traditional linguistic studies and the argumentative and discursive construction according to disciplinary norms. Some other studies were found focused on rhetorical aspects and their operation within the professional environment, especially in oral trials. Despite the statement above is directly related to literacy, the importance of social and cultural context on the comprehension and textual production, including the disciplinary field, is not deeply outlined.

From the bibliographic revision, however, the following initial categories were identified: discursive genres, (legal) field, (legal) argumentation, and inter-textuality. Work with these categories allowed developing the field work in order to apply the questionnaire to students, the interview to professors, and the focal group to alumni.

The questionnaire to students included an inquiry about their perceptions about: writing practices, professors' guidance, and reading practices. By comparing through the instrument to the theoretically established concerning the literacy practices, it was verified that there was no a significant statistical difference. This means that students recognize and value a number of exercises and practices at the classroom relating to reading and writing and they associated them to the legal field. Likewise, it was found that they view these practices as a merely instrumental action.

All professors who were administered an interview coincidentally affirmed that comprehension and textual production are significantly relevant for the educational processes and the professional practice in the legal field. However, a deficiency associated to concepts of applied linguistics which could enrich the pedagogical work and develop better levels of student's literacy was observed. During the analysis of interviews, some new categories emerged: didactics, textual practices, and orality. This coincides with the research tendencies described above, since interviewed professors, when talking about textual practice, make a specific reference to spelling and grammar. The argumentative exercise, however, is associated to works on logics and the way premises are constructed.

Finally, results obtained through the focal group of alumni allowed establishing that despite the ignorance on the literacy concept in the legal field, alumni acknowledge practices relating to their education and professional performance. However, they express a disagreement between the use given to comprehension and textual production during their education and the one they require during their professional practice. In terms of literacy, this may refer to the lack of knowledge on contexts and discursive genres in the pedagogical practices offered during the education process and to the disconnection of pedagogical practices with the professional performance contexts. 


\section{Conclusions}

The study allowed noticing that literacy in the legal field offers a significant number of discursive genres with different super-structures and different pragmatic uses. This necessarily impacts any reference made to teaching. If pedagogical practices consider literacy, the context for comprehension and textual production plays a fundamental role. Thus, professors require the specific knowledge of the discipline, the recognition of present linguistic elements, and the performance of an intentional use of practices with students.

Professors participating in the study apparently show no recognition of the potential employment of literacy for the meta-cognitive process relating to the education and professional performance. This further implies that they think that students should have the level of literacy expected when starting the professional program and they do not envision that the pedagogical exercise of comprehension and textual production within the framework of the specific knowledge may enhance the discursive competences of a future attorney or his/her cognitive processes.

Statements of alumni within the focal group are a reinforcement of the above, since they affirm that their performance implies the development of activities which involve literacy practices through some disciplinary discursive genres that were not expressly considered during their education process. This allows thinking about the problem with the education of professionals at a higher-education level based on the literacy as a potential enhancer of the disciplinary knowledge. Therefore, teaching how to read and write at the university is mandatory from a specific knowledge (context).

\section{References}

Alexander, P. (2017). Reflection and reflexivity in practice versus in theory: Challenges of conceptualization, complexity, and competence. Educational Psychologist, 52(4), 307-314, from: https://www.tandfonline.com/doi/abs/10.1080/00461520.2017.1350181

Ander-Egg, E. (2003). Métodos y técnicas de la investigación social. Tomo IV: Técnicas para la recogida de datos e información. Buenos Aires: Lumen.

Brown, D. (1999). Reading, Writing, and Regime Type: Democracy' Impact on Primary School Enrollment. Political Research Quarterly, 52(4), 681-707, from: https://journals.sagepub.com/doi/abs/10.1177/106591299905200401

Bonilla, E. y Rodríguez, P. (1997), Más allá del dilema de los métodos, Bogotá, Ediciones Uniandes, Grupo Editorial Norma.

Carlino, P. (2005). Escribir, leer y aprender en la universidad. Una introducción a la alfabetización académica. Buenos Aires: Fondo de Cultura Económica.

Cassany, D. (2005). Investigaciones y propuestas sobre literacidad actual: multiliteracidad, internet y criticidad. Cátedra UNESCO para la lectura y la escritura. Chile: Universidad de Concepción.

Giroux, H., \& McLaren, P. (2018). Writing from the margins: Geographies of identity, pedagogy, and power. In Revolutionary multiculturalism (pp. 16-41). Routledge.

Heigham, J., \& Croker, R. (Eds.). (2009). Qualitative research in applied linguistics: A practical introduction. Springer.

Londoño, D. (2015). Jóvenes y literacidad: Un análisis sociolingüístico. Medellín: Editorial Sello IUE.

Londoño, D., \& Ramírez, Á. (2017). La institucionalización de la escritura académica: desde la adquisición del código hasta la publicación. Revista de Letras, 57(2), 141-158, from: https://www.jstor.org/stable/26577792?seq=1\#page_scan_tab_contents

López Ferrero, C. (2002). Aproximación al análisis de los discursos profesionales. Revista signos, 35 (51-52), 195-215, from: $\quad$ https://scielo.conicyt.cl/scielo.php?pid=S071809342002005100013\&script $=$ sci_arttext

Navarro, F., Ávila Reyes, N., Tapia-Ladino, M., Cristovão, V. L., Moritz, M., Narváez Cardona, E., \& Bazerman, C. (2016). Panorama histórico y contrastivo de los estudios sobre lectura y escritura en educación superior publicados en América Latina. Revista signos, 49, 78-99. https://scielo.conicyt.cl/scielo.php?pid=S0718-09342016000400006\&script=sci_arttext\&tlng=e

Özdem, Y., Cakiroglu, J., Ertepinar, H., \& Erduran, S. (2017). The pedagogy of argumentation in science education: science teachers' instructional practices. International Journal of Science Education, 39(11), 1443-1464, from: https://www.tandfonline.com/doi/abs/10.1080/09500693.2017.1336807

Parodi, G. (2008). Géneros académicos y géneros profesionales: Accesos discursivos para saber y hacer. Valparaíso: Ediciones Universidad de Valparaíso.

Patton, M. (1990). Qualitative evaluation and research methods. SAGE Publications, inc. 
Roberge, M., Losey, K., \& Wald, M. (Eds.). (2015). Teaching US-educated multilingual writers: Pedagogical practices from and for the classroom. University of Michigan Press.

Rosenshine, B. (2017). Skill hierarchies in reading comprehension. In Theoretical issues in reading comprehension (pp. 535-554). Routledge.

Skerrett, A., \& Bomer, R. (2011). Borderzones in adolescents' literacy practices: Connecting out-of-school literacies to the reading curriculum. Urban Education, 46(6), 1256-1279.

Vaughn, S., Schumm, J., \& Sinagub, J. (1996). Focus group interviews in education and psychology. Sage.

Zavala, V. (2009). La literacidad o lo que la gente hace con la lectura y la escritura. En D. Cassany, Para ser letrados (pp. 23-35). Barcelona: Ediciones Paidós Ibérica, S.A. 